be emotional, and I hope to be able to shew the practical advantagee of this method. Emotion regarded as a form of feeling attitude is connected with a permanent festure of our psychical constitution. It thus ceases to be an anomaly, and can be shewn to play an intelligible part in our mental life. This seems a matter of no slight importance, and a physiological theory will always fail in this regard. It gives emotion a place but not a function in the constitution of our nature.

David Irons.

\title{
THE THEORY OF JUSTICE.
}

THE strong point of modern a priori ethical systems has on the whole been the theory of justice. Powerful attempts, such as that of Hobbes, have been made to derive its formulae and to establish its obligation on experiential grounds, but these have always seemed to leave something unexplained. Among recent theories on assentially the same lines may be mentioned that of W. H. Rolph, in his Biologische Probleme-a book to the distinctive ethical point of which justice was scarcely done in a review that appeared in Mind, vol. x. 281. A later attempt, in conscious dependence on Hobbes, is Mr Hugh Taylor's Morality of Nations (see Mind, xIII. 287, 425). This is worked out from the point of view of the special student of society; Rolph's starting-point being rather that of the naturalist. The essence of the doctrine in all its expressions is that the formulae of justice are the result of a conflict among societies, or among individuals; and that they are fundamentally "contractual," and suppose, in their abstract expression, the equality, in the particular relations involved, of the persons contracting. The formulae, when we appeal, as we must finally, to the ends for which they exist, have an egoistic reference. Their justification is that the interests of the individual are best attained by observing them in all cases.

Although there is a large portion of truth in this theory, it cannot quite maintain itself on its ground of pure egoism. When we suppose the rules of justice established by convention, we have to bring in some element of sympathetic imagination, or some intrinsic social character of men, before we can effectively get our formulse reslised in action. Purely egoistic social units neither could nor would consistently practise the rules of justice. These rules, if we sllow their partial origin in egoistic conflict, must somehow be attached to the sympathetic impulses that issue more directly in another class of virtues. Thus Hume, deducing the virtues of benevolence directly fron sympathy, was able to incorporate in his. ethics, with some modification, the theory of the egoistic origin of justice. According to Hume, in a society of which all the members were perfectly benevolent, justice would be superseded. It has its 
true place in a society of which the members are neither wholly selfish nor wholly sympathetic.

If, however, we put justice in a lower place, then we are reducing to a subordinate rank a virtue that seems clearer in its obligation than any other. This is the point that can always be made by the a priori thinkers. The experientialist may indeed avoid part of the difficulty by taking the question on psychological instead of on distinctly ethical ground. According to the a priori moralist the formulae of justice are expressive of certain objective relations, and indicate the rule to be followed apart from any consideration of consequences. They have an immediate and intrinsic reasonableness. The equalities and proportions they require are something that ought to be apart from any end beyond themselves. The experientialist, on the other hand, cannot adunit that they are obligatory in themselves and apart from all consideration of ends-that is, ultimately, apart from all subjective feeling in any individual. $\mathrm{He}$ may, however, give a psychological explanation of their peculiar characteristics. Their appearance of being specially obligatory may be explained as the impress left by the coercive action of the State in enforcing those moral rules that are necessary for its preservation. Their special clearness may be regarded as an aesthetic impression due to a certain quasi-mathematical character they have. The real reason why they have this character is, it may be said, because, in questions of distribution, we must have some fixed rule, and it is easiest to take that which is intellectually simplest. As a psychological fact, there is a certain pleasure in contemplating the relations the rules of justice suppose, and a certain pain in coutemplating their derangement, quite apart from all consideration of consequences. Ethically, any formula would be good that could be got to work, but a formula not admitting of sufficient abstraction and generality fails to impress itself aesthetically. In themselves the laws of justice are simply one set of rules among others, specially important in view of the ends to be subserved by them; but, in pure ethics, the aesthetic character they derive from their simplicity is not to the point.

Still, after all psychological explanations, an answer has to be given to the rational question why the rules of justice ought to be observed. The experientialist must at last fall back on the position that justice owes its peculiar place in ethics in some way to the end for which it exists.

One great gain that has come to ethics from the theory of evolution is that the necessity of a social basis has been made clearer than it ever was before. Without social conservation no other end can permanently be attained. Hence the virtues by which the social organism is preserved are the most important of all. On evolutionary, as well as on general utilitarian grounds, this position has been assigned to justice. Because of its special importance for social conservation justice alone, or justice most of all, it has been contended by Mr Spencer, ought to be enforced by legal 
penalties. Associations of its infraction with punishment, we may add from Prof. Bain's analysis, cause the appearance to go along with the reality of superior obligation.

Still, it is only on the rougher forms of justice that social stability can be said with truth to depend; on kinds of abstinence from aggression that are scarcely entitled to the name of a distinctive virtue. Mr Spencer has pointed out in his Principles of Ethics that the distinctive virtue of justice receives no formulation in the moral codes that have ruled over Eastern civilisations. Compassion, in all its forms, is obviously a different virtue from justice; and so also is strictness in carrying out the precepts of an authoritative code, though this is less obvious. In truth, justice as a special virtue was first distinctly conceived in Greece. Early poets and thinkers made attempts at its formulation. Plato made an exceedingly elaborate attempt, but in the end defined as "justice" something-namely the performance of its proper functions by each part of the State and by each part of the individual soul-which has never in any community been recognised as the distinctive virtue signified by that name. Aristotle returned to the problem, and succeeded in fixing the general conception as something that relates to distributions of social goods, and as taking for its intellectual basis relations of proportionate equality. In the development of European thought, the increased definiteness it has got since has come to a great extent from analysis of legal conceptions.

What emerges from historical consideration is thus not that justice in the distinctive sense is specially connected with the stability of all societies. Some at least of the Asiatic civilisations have been exceedingly stable. Yet in Asiatic societies the equalities and reciprocal obligations involved in the conception of justice have never come into clear consciousness. On the other side, European States, so far as experience can say up to the present, have been less stable than the more permanent States of the Eastern world; but the conception of justice has appeared, and has received more and more distinct formulation. What ground then must the experientialist take if he wishes to bring justice finally into relation with an ethical end, and is not satisfied with its presentation as an abstract formula bearing its own evidence in its aesthetic or intellectual character?

A ground seems attainable in the following way. The science of society may be considered as having reference either to societies so far as they are merely social aggregates, or so far also as they have political structure. In its general part the science of society might be called anthropology, in its special part political history. There is a corresponding distinction among the ethical virtues. Some have a general social reference; others have also a political reference. Over and above his existence as a unit in the social organism, the individual man may be a member of a free State. Now the ethical virtue of justice has always been understood to have a special con- 
nexion with political ends. It has never been found possible to treat it adequately without reference to the State. If, taking it as an ethical virtue, we define it as that virtue which, when observed between individuals, tends to the preservation, or to the establishment, of a State of particular type, then we have a ground for marking it off from the other virtues. Obviously it both becomes distinctly defined in States involving relations between political equals who are also free-whether constituting the whole of the State or notand, when practised, tends to the preservation of such States. Thus we are able to refer it to an impersonal end which at the same time the individual can regard with desire. If happiness is most attainable in a State that is politically free, then the end has the subjective meaning which, for the experientialist, is inseparable from it. A set of objective relations is indeed involved, as the $a$ priori thinkers maintain, but they have somewhere as their accompaniment feelings that spring from the activity of personalities. The subjective end being thus definitely assignalle, a ground can now be given from the comparison of sucieties for placing justice above the other virtues. For it is the virtue that tends to maintain in existence, or to bring about, or to extend, the best type of political society. And, as ancient thinkers saw, only in the best type of political society can the best type of individual existence be realised.

T. WhitTAKer. 